\title{
Mortality study of nickel-cadmium battery workers by the method of regression models in life tables
}

\author{
T SORAHAN AND J A H WATERHOUSE
}

From the Cancer Epidemiology Research Unit, Department of Social Medicine, University of Birmingham, Edgbaston, Birmingham, B15 2TH, UK

ABSTRACT The mortality experienced by a cohort of 3025 nickel-cadmium battery workers during the period 1946-81 has been investigated. Occupational histories were described in terms of some 75 jobs: eight with "high", 14 with "moderate" or slight, and 53 with minimal exposure to cadmium oxide (hydroxide). The method of regression models in life tables (RMLT) was used to compare the estimated cadmium exposures (durations of exposed employment) of those dying from causes of interest with those of matching survivors in the same year of follow up, while controlling for sex, for year and age of starting employment, and for duration of employment. No new evidence of any association between occupational exposure to cadmium oxide (hydroxide) and cancer of the prostate was found.

This study analyses the mortality experience of a group of nickel-cadmium battery workers by the method of regression models in life tables (RMLT). Before the data were first analysed, ${ }^{1}$ the main hypotheses of interest were listed in order to minimminimise multiple testing and the generation, purely by chance, of some significant results. The hypotheses were arrived at on the basis of other epidemiological findings and published hypotheses formulated on the basis of known physiological effects of cadmium.

In 1965 Potts reported three deaths from cancer of the prostate from a total of eight deaths occurring among 74 workers exposed to cadmium for more that 10 years in the factory described here. ${ }^{2}$ Subsequently, the results of a cancer morbidity study performed on a subset of the present data were reported by Kipling and Waterhouse in 1967, who noted a statistically significant excess incidence of cancer of the prostate (Expected $=0.58$, Observed $=4, \mathrm{p}<0.01){ }^{3}$ Any effect found, therefore, in the present analysis would have to be shown independently of the four cases described in the above report to qualify as new evidence.

In a mortality study of cadmium smelter workers Lemen $e t$ al found an excess of cancer of the prostate $($ Expected $=1 \cdot 15$, Observed $=4),{ }^{4}$ all deaths occurring more than 20 years from first exposure

Received 19 July 1982

Accepted 26 August 1982
(Expected $=0 \cdot 88$, Observed $=4)$; an excess mortality from cancers of the respiratory system was also reported in this study (Expected $=5 \cdot 11$, Observed $=12, p<0 \cdot 05$ ). In 1980 Holden reported an excess mortality from cancer of the prostate among cadmium "vicinity" workers, ${ }^{5}$ but no such effect was found in a group of "highly exposed" workers or in a control group of brass foundry workers (highly exposed workers; Expected $=1 \cdot 58$, Observed $=1$ : "vicinity" workers; Expected $=3 \cdot 00$, Observed = 8: control group; Expected $=1 \cdot 04$, Observed $=0$ ).

Occupational exposure to cadmium can lead to the development of a low molecular weight (LMW) proteinuria ${ }^{67}$ believed to be due to the accumulation of cadmium in the proximal renal tubules. Possibly, therefore, the largely asymptomatic effects of cadmium on renal function may increase the risk of mortality from nephritis and nephrosis (together with other diseases of the genitourinary system). Furthermore, it has been suggested that this effect on renal function might produce hypertension and thus influence mortality from diseases of the circulatory system. Chronic cadmium poisoning (from cadmium fume) can also produce severe dyspnoea due to emphysema.

The hypotheses to be tested, then, were as follows:

Is there an association between occupational exposure to cadmium oxide (hydroxide) dust and

(1) cancer of the prostate,

(2) cancers of the respiratory system,

(3) diseases of the circulatory system - particu- 
larly those related to hypertension,

(4) nephritis and nephrosis, and other diseases of the genitourinary system, and

(5) diseases of the respiratory system (noncancer)?

Results relating to mortality from nephritis and nephrosis and other diseases of the genitourinary system have been reported separately. ${ }^{8}$

\section{Study material}

\section{FACTORY CONDITIONS}

The nickel-cadmium battery factory under investigation had been originally two concerns that amalgamated in 1947: factory $A$ which opened in 1937 and factory B which opened in 1923 and closed after the amalgamation. The nature of the occupational cadmium exposure has been reported elsewhere $^{27}$ : it takes the form of cadmium oxide (hydroxide) dust, and in the early factories there was little local exhaust ventilation. The cadmium content of the air was first estimated in 1949: in the platemaking and assembly shops, concentrations ranged from 0.6 to $2.8 \mathrm{mg} / \mathrm{m}^{3}$, and in the negative active material department-where the cadmium oxide powder is prepared-the concentration was considerably higher. After installation of extensive local exhaust ventilation in 1950 , cadmium in air levels were reduced to below $0.5 \mathrm{mg} / \mathrm{m}^{3}$ in most parts of the factory. Further improvements in exhaust ventilation have been installed over the years, and in 1967 a new platemaking department was built and working conditions below the then recommended threshold limit value (TLV) of 0.2 $\mathrm{mg} / \mathrm{m}^{3}$ for cadmium oxide dust were achieved. Since 1975 , the plant has operated at levels within the current TLV of $0.05 \mathrm{mg} / \mathrm{m}^{3}$.

\section{STUDY POPULATION}

The study population and its overall mortality have been described elsewhere, ${ }^{1}$ but the study cohort may be summarised as 3025 workforce employees (2559 men and 466 women) who started employment between 1923 and 1975 and had a minimum period of employment of one month.

The Office of Population Censuses and Surveys

Table 1 Study population: vital status at end of survey 31 January 1981

\begin{tabular}{lrr}
\hline & No & \multicolumn{1}{c}{$\%$} \\
\hline Traced alive & 2184 & $72 \cdot 2$ \\
Traced dead & 693 & 22.9 \\
Emigrated & 68 & $2 \cdot 3$ \\
Not traced & 80 & $2 \cdot 6$ \\
Total & 3025 & $100 \cdot 0$ \\
\hline
\end{tabular}

provided information on the vital status of each individual on the closing date of the survey, 31 January 1981 (table 1). (There were 164 workers for whom insufficient information was available for tracing by the OPCS, and details of these were sent to the central offices of the Department of Health and Social Security at Newcastle for tracing using National Insurance numbers.) For those who had died, a death certificate was obtained with the underlying cause of death coded to the 8th revision of the ICD. Some 80 workers $(2.6 \%)$ remained untraced. Mortality was investigated for the period 1 January 1946 to 31 January 1981.

Detailed job histories-defined in terms of some 75 jobs-were coded for each workèr. Eight jobs (relating to the platemaking, assembly, and negative active material departments) were considered to entail high exposure to cadmium, 14 to entail moderate (or slight) exposure to cadmium, and 53 to entail minimal exposure to cadmium (table 2). For each worker and for each year of follow up the duration and cumulative duration of (1) high exposure employment and (2) high or moderate exposure employment were calculated.

\section{Table 2 Job categories by exposure to cadmium}

\section{High exposure \\ Assembly, miniature cell assembly, small cell assembly, sintered assembly, main assembly, negative active material, platemaking, sintered platemaking}

Moderate (or slight) exposure

Maintenance, building maintenance, bricklayer, electricians, factory cleaning, inspection, millwrights, painter, pipefitting, quality control, repair shop, scrap recovery, shop sweeper, welding

\section{Minimal exposure}

Annealing, blacksmith, bobbin (dry cell), boilerman, canteen, cell plating, charge shop, chemical laboratory, carpenter, despatch, dry cell filling, engine driver, research and development, final assembly, formation, fork lift driver, transport, garage, groundsman, gate duty, iron lamp assembly, lamp shop, lead mill, lead paster, machine shop, mine lamp assembly, nickel flake, nickel plating, office cleaner, offices, packing, perforating, plating, polisher, positive active material, press shop, plastic assembly, ribbon plating, shop blasting, spraying, stores, technical department, test room, tool room, truck driver, tube assembly, tube department, van driver, woodshop, warehouseman, work study, yard labourer

\section{Methods}

The mortality experience of this cohort was compared with that which might have been expected to occur if rates of mortality for the general population of England and Wales had been operating on the study cohort, having due regard to the composition of the study cohort by age and sex and calendar year. Expected numbers of deaths were calculated using the Manyears program developed by $\mathrm{J}$ Peto. This placed the mortality experience of the study cohort in broad perspective. The differences found 
between the observed mortality of an industrial cohort and its expected experience based on the rates of mortality for the general population, however, are clearly dependent on factors other than the specific occupational exposure. ${ }^{9}$ Such factors will include selection effects within the workforce as well as the social class and regional composition of the study cohort. The method of regression models in life tables (RMLT), therefore, was used to test the null hypothesis of no effect on mortality from occupational exposure to cadmium. The method of RMLT was developed by Cox, who has given examples of its use in the analysis of clinical trials ${ }^{10}$; the method has been used by Kneale in a cohort mortality study of radiation workers and it is Kneale's use of the method that is described here. ${ }^{11}$

The method is applied in two parts; firstly, a test of the null hypothesis of no effect from the exposure and, secondly, if the null hypothesis is rejected the estimation of parameters for dose effect models by maximum likelihood techniques.

The method was used to compare the estimated cadmium exposures of those who died in a given year of follow up with those of matching survivors in the same year of follow up while controlling for sex, year of hire (1923-, 1940-, 1947-, 1957-, > 1967), age at hire (15-, 20-, 30-, 40-, > 50), and duration of employment in years/employment status $(0-, 1-$, $\geqslant 6$ or still employed).

The data were first divided into a large number of subgroups by levels of the "controlling variables" mentioned above. For each subgroup a life table was constructed giving, for each year of follow up, the total number entering the year and the number dying from the cause under investigation with the estimated cumulative cadmium exposures for these two categories (see statistical appendix).

Exposure to cadmium was estimated in two ways: cumulative duration of employment in a high exposure job (exposure estimate 1) and cumulative duration of employment in a high or moderate exposure job (exposure estimate 2). The null hypothesis of no effect on mortality from the exposure is that the deaths in each year of follow up are a random sample from the entrants to that year, and that the difference in the mean cumulative exposures of these two categories should be zero.

A test-statistic, which is asymptotically normally distributed, was calculated to determine the probability of observing by chance alone the difference found between the exposures of those who have died and the exposures of the matching survivors-that is, if the null hypothesis of no effect on mortality from the exposure is true. Thus with a test-statistic of greater than 1.96 , the null hypothesis is rejected at the $5 \%$ level.

Once the controlling variables used have been shown to be adequate (by examining the change in the test-statistic for all causes of death on the addition of successive variables) the null hypotheses relating to cause specific mortality may be tested.

\section{Results}

\section{OVERALL MORTALITY: SMR METHOD}

Table 3 shows observed and expected numbers of deaths for causes under investigation by sex and by year of starting employment for men only.

Compared with the general population of England and Wales, there is a deficit of deaths from diseases of the circulatory system $(\mathrm{SMR}=89)$; this finding is statistically significant at the $5 \%$ level. The excess for cancers of the respiratory system (SMR = 127 ) is also statistically significant at the $5 \%$ level. SMRs for all causes, all cancers, and diseases of the respiratory system are 97,109 , and 112 respec-

Table 3 Mortality $1946-81 \dagger$

\begin{tabular}{|c|c|c|c|c|c|c|c|c|c|c|c|c|c|}
\hline \multirow[t]{2}{*}{ Cause of death } & \multirow[t]{2}{*}{$I C D 8 t h$} & \multicolumn{3}{|c|}{$E a \ddagger m e n$} & \multicolumn{3}{|c|}{ La§ men } & \multicolumn{3}{|c|}{ All women } & \multicolumn{3}{|c|}{ All employees } \\
\hline & & $\operatorname{Exp}$ & Obs & $(S M R)$ & $\operatorname{Exp}$ & Obs & $(S M R)$ & $\operatorname{Exp}$ & Obs & $(S M R)$ & $\operatorname{Exp}$ & Obs & $(S M R)$ \\
\hline $\begin{array}{l}\text { Cancer of respiratory system } \\
\text { Cancer of prostate } \\
\text { All cancers } \\
\text { Diseases circulatory system } \\
\text { Diseases respiratory system } \\
\text { All causes other than cancer } \\
\text { All causes }\end{array}$ & $\begin{array}{l}160-163 \\
185 \\
140-209 \\
390-458 \\
460-519\end{array}$ & $\begin{array}{r}42 \cdot 4 \\
4 \cdot 5 \\
98 \cdot 4 \\
193 \cdot 3 \\
54 \cdot 2 \\
305 \cdot 7 \\
404 \cdot 1\end{array}$ & $\begin{array}{r}52 \\
5 \\
93 \\
163 \\
58 \\
275 \\
368\end{array}$ & $\begin{array}{r}(123) \\
112) \\
(95) \\
(84) * \\
(107) \\
(90) \\
(91)\end{array}$ & $\begin{array}{r}25 \cdot 6 \\
2 \cdot 1 \\
58 \cdot 5 \\
107 \cdot 8 \\
27 \cdot 4 \\
168 \cdot 7 \\
227 \cdot 2\end{array}$ & $\begin{array}{r}35 \\
3 \\
76 \\
108 \\
35 \\
176 \\
252\end{array}$ & $\begin{array}{l}(137) \\
142 \\
130) \\
100) \\
128 \\
104 \\
111)\end{array}$ & $\begin{array}{r}2 \cdot 2 \\
20 \cdot 7 \\
28 \cdot 1 \\
6 \cdot 7 \\
49 \cdot 7 \\
70 \cdot 4\end{array}$ & $\begin{array}{r}2 \\
24 \\
23 \\
6 \\
35 \\
59\end{array}$ & $\begin{array}{l}(91) \\
(116) \\
(82) \\
(70) \\
(84)\end{array}$ & $\begin{array}{r}70 \cdot 2 \\
6 \cdot 6 \\
177 \cdot 6 \\
329 \cdot 2 \\
88 \cdot 3 \\
524 \cdot 1 \\
701 \cdot 7\end{array}$ & $\begin{array}{r}89-1 \\
8 \\
193 \\
294 \\
99 \\
486 \\
679\end{array}$ & $\begin{array}{r}(127)^{*} \\
121) \\
109) \\
(89) \\
(112) \\
(93) \\
(97)\end{array}$ \\
\hline
\end{tabular}

†Expectations based on rates of mortality in England and Wales (1946-78) except for diseases of the respiratory system women (1951-75) and diseases of the circulatory system women (1968-77).

†Ea men, early employments, pre-amalgamation 1923-46.

$\S \mathrm{La}$ men, late employments, post-amalgamation 1947-75.

ๆComprised two deaths from cancer of larynx (ICD 8:161), 86 from cancer of trachea, bronchus, and lung (ICD 8:162), one death from cancer other unspecified respiratory (ICD 8:163).

${ }^{*} \mathrm{p}<0.05$. 
Table 4 Study cohort by levels of controlling variables (total in subgroup with numbers of deaths)

\begin{tabular}{|c|c|c|c|c|c|c|c|}
\hline \multirow{2}{*}{$\begin{array}{l}\text { Age at starting } \\
\text { employment }\end{array}$} & \multirow[t]{2}{*}{ Sex } & \multicolumn{5}{|c|}{ Year of starting employment } & \multirow{2}{*}{$\begin{array}{l}\text { Total } \\
(M+F)\end{array}$} \\
\hline & & $1923-$ & $1940-$ & $1947-$ & $1957-$ & $\geqslant 1967$ & \\
\hline $15-$ & $\mathbf{M}$ & $344 / 68$ & $88 / 11$ & $31 / 0$ & $51 / 1$ & $12 / 0$ & $594 / 83$ \\
\hline 20 & $\begin{array}{l}\mathbf{F} \\
\mathbf{M}\end{array}$ & $\begin{array}{c}3 / 0 \\
269 / 88\end{array}$ & $\begin{array}{l}44 / 3 \\
75 / 21\end{array}$ & $\begin{array}{l}15 / 0 \\
199 / 20\end{array}$ & $\begin{array}{r}6 / 0 \\
200 / 5\end{array}$ & $\begin{array}{r}0 / 0 \\
197 / 2\end{array}$ & $1173 / 154$ \\
\hline & $\mathrm{F}$ & $\begin{array}{c}209 / 00 \\
2 / 1\end{array}$ & $112 / 16$ & $\begin{array}{c}199 / 20 \\
83 / 1\end{array}$ & $27 / 0$ & $\begin{array}{r}19 / / 2 \\
3 / 0\end{array}$ & $11 / 3 / 134$ \\
\hline $30-$ & $\mathbf{M}$ & $61 / 38$ & $103 / 48$ & $148 / 38$ & $122 / 13$ & $85 / 1$ & $606 / 159$ \\
\hline & $\mathbf{F}$ & $1 / 1$ & $43 / 18$ & $25 / 1$ & $12 / 1$ & $6 / 0$ & \\
\hline $40-$ & $\mathbf{M}$ & $6 / 4$ & $24 / 19$ & $141 / 79$ & $78 / 19$ & $58 / 5$ & $358 / 135$ \\
\hline & $\mathrm{F}$ & $1 / 0$ & $2 / 1$ & $21 / 8$ & $22 / 0$ & $5 / 0$ & \\
\hline$\geqslant 50$ & $\mathbf{M}$ & $1 / 1$ & $7 / 7$ & $32 / 20$ & $67 / 28$ & $49 / 8$ & $181 / 68$ \\
\hline Tol & $\mathbf{F}$ & $1 / 0$ & $1 / 0$ & $7 / 2$ & $10 / 2$ & $6 / 0$ & \\
\hline Total $(M+F)$ & & $689 / 201$ & $499 / 144$ & $702 / 169$ & $601 / 69$ & $421 / 16$ & 2912/599 \\
\hline
\end{tabular}

$\mathrm{x} / \mathrm{y}$ where $\mathrm{x}=$ total in sub-group; $\mathrm{y}=$ number that die in study period among the $\mathrm{x}$ entrants.

tively. For each cause of death shown, the SMR for Ea men (early employments) is lower than that for La men (late employments).

\section{ANALYSIS BY THE METHOD OF RMLT}

This analysis is based on different numbers from those shown in the preceding section because 113 workers whose job histories were either not available or inadequately described were excluded.

Table 4 shows the total number of workers together with the number of deaths occurring among them by sex, age of starting employment, and year of starting employment. The classification by "duration of employment" is not shown as an individual can appear in more than one subgroup. Thus a worker who left the company after four years' employment would be in a " $\geqslant 6$ or still employed" subgroup for the first four years of follow up and would then be transferred to a " $1-5$ " subgroup for the remainder of the study period.

Table 5 shows test-statistics for all causes of death obtained from introducing different sets of controlling variables. The addition of "age at starting employment" is sufficient to reduce a highly significant statistic $(3 \cdot 29)$ to insignificance $(0 \cdot 69)$.

Table 5 Effect of introducing controlling variables. Testing the null hypothesis of no effect from occupational exposure to cadmium on all causes of death (599 deaths) by the method of RMLT

\begin{tabular}{|c|c|}
\hline Controlling variables & $\begin{array}{l}\text { Test-statistic } \\
\text { Exposure estimate } 1 \dagger\end{array}$ \\
\hline $\begin{array}{l}\text { No controls } \\
\text { Sex }+ \text { year of starting employment }\end{array}$ & $\begin{array}{l}3 \cdot 43^{* * *} \\
3 \cdot 29^{* * *}\end{array}$ \\
\hline $\begin{array}{l}\text { Sex + year of starting employment } \\
+ \text { age at starting employment } \\
\text { + duration of employment }\end{array}$ & $\begin{array}{l}0.69 \\
0.61\end{array}$ \\
\hline
\end{tabular}

$\dagger$ Exposure = duration of employment in a "high" exposure job. ${ }^{* * *} \mathrm{p}<0.001$
The addition of duration of employment, however, had surprisingly little effect, but it has been included in the following analyses because of its general importance concerning selection effects within industrial cohorts, although analyses were also performed without the inclusion of duration of employment as a controlling variable.

Table 6 shows test-statistics comparing the exposures of those who have died from the causes of death under investigation with those of all matching survivors. The statistics for diseases of the circulatory system $(0.35,0.60)$, diseases of the circulatory system associated with hypertension $(0 \cdot 89,1 \cdot 06)$, and bronchitis, emphysema, and asthma $(-1.45,0.06)$ are not statistically significant. Large test-statistics are shown for cancer of the prostate $(3 \cdot 19,2 \cdot 04)$ but the relatively small number of deaths on which these statistics are based make the estimation of a precise p-value difficult. Simulations carried out would indicate, however, that the test-statistic of 3.19 obtained for exposure estimate 1 is statistically significant at the $5 \%$ level. The test-statistics for cancers of the respiratory system are 1.28 and 2.52 , that for exposure estimate 2 being statistically significant at the $5 \%$ level.

The method readily allows an inspection of the contributions from subcohorts to the overall teststatistic, and table 7 shows statistics by levels of controlling variables for mortality from cancers of the respiratory system.

The significance of the overall test-statistic for exposure estimate 2 can be seen to be dependent on the statistic relating to deaths occurring among those first employed in the period 1923-39. It is this group of workers which dominates the " $\geqslant 30$ years of follow-up" group.

Table 7 also shows test-statistics for exposure estimated as duration of employment in a high or moderate exposure job (excluding welding). This latter job entailed exposure to fumes from oxy- 
Table 6 Testing the null hypothesis of no effect from occupational exposure to cadmium on causes of death under investigation by the method of RMLT†

\begin{tabular}{|c|c|c|c|c|c|c|c|c|}
\hline \multirow[t]{2}{*}{ Cause of death } & \multirow[t]{2}{*}{$I C D 8 t h$} & \multirow{2}{*}{$\begin{array}{l}\text { No of } \\
\text { deaths }\end{array}$} & \multicolumn{3}{|c|}{ Exposure estimate $1 \S$} & \multicolumn{3}{|c|}{ Exposure estimate $2 \|$} \\
\hline & & & $\begin{array}{l}\text { Mean } \\
\text { exp } \\
\text { deaths }\end{array}$ & $\begin{array}{l}\text { Mean } \\
\text { deviation } \\
\text { in exp }+\dagger\end{array}$ & $\begin{array}{l}\text { Test- } \\
\text { statistic }\end{array}$ & $\begin{array}{l}\text { Mean } \\
\text { exp } \\
\text { deaths }\end{array}$ & $\begin{array}{l}\text { Mean } \\
\text { deviation } \\
\text { in exp }+\dagger\end{array}$ & $\begin{array}{l}\text { Test- } \\
\text { statistic }\end{array}$ \\
\hline $\begin{array}{l}\text { Cancer of prostate } \\
\text { Cancer of respiratory system } \\
\text { Diseases of circulatory system } \\
\text { Associated with hypertension } \\
\text { Remainder } \\
\text { Diseases of respiratory system } \\
\text { Bronchitis, emphysema, asthma }\end{array}$ & $\begin{array}{l}185 \\
160-163 \\
390-458 \\
\ddagger \\
460-579 \\
490-493\end{array}$ & $\begin{array}{r}8 \\
82 \\
255 \\
214 \\
41 \\
84 \\
53\end{array}$ & $\begin{array}{l}8 \cdot 2 \\
2 \cdot 7 \\
2 \cdot 0 \\
2 \cdot 2 \\
1 \cdot 0 \\
2 \cdot 2 \\
2 \cdot 0\end{array}$ & $\begin{array}{r}6 \cdot 1 \\
0.7 \\
0.1 \\
0.3 \\
-0.9 \\
-0.5 \\
-1 \cdot 2\end{array}$ & $\begin{array}{r}3 \cdot 19^{*} \\
1.28 \\
0.35 \\
0.89 \\
-1.17 \\
-0.79 \\
-1.45\end{array}$ & $\begin{array}{l}9 \cdot 6 \\
6 \cdot 1 \\
3 \cdot 9 \\
4 \cdot 2 \\
2 \cdot 4 \\
5 \cdot 2 \\
5 \cdot 2\end{array}$ & $\begin{array}{r}5 \cdot 2 \\
2 \cdot 0 \\
0.2 \\
0.5 \\
-1 \cdot 0 \\
0.4 \\
0.1\end{array}$ & $\begin{array}{r}2.04 \\
2.52^{*} \\
0.60 \\
1.06 \\
-1.08 \\
0.50 \\
0.06\end{array}$ \\
\hline
\end{tabular}

*p $<0.05$.

†Controlling for sex, year of starting employment, age at starting employment, and duration of employment.

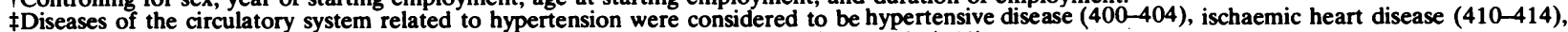

cerebrovascular disease excluding subarachnoid haemorrhage (431-438), arteriosclerosis (440).

$\S$ Exposure $=$ duration of employment in a high exposure job.

Exposure = duration of employment in a high or moderate exposure job.

In units of years of exposed employment.

++ Mean deviation in exposure between those dying from a particular cause, and matching survivors, in units of years of exposed employment.

acetylene welding and such exposure could in itself be a potential risk factor for cancers of the respiratory system. Test-statistics for exposure estimate 3 are reduced to values below the level at which statistical significance occurs.

It is clear from descriptions and photographs of conditions in the factory in prewar years and from the progressive improvements in exhaust ventilation made since 1950 that exposures received by workers at present are only a fraction of those received by workers with a similar job description 30 or 40 years ago. The procedure described of considering exposure to be proportional to cumulative duration of employment in a high exposure job is thus liable to serious bias. (It should not lead, however, to the generation of statistical significance other than that predicted by chance alone, as the estimation of exposure was carried out independently of knowledge of the deaths.)

Routine cadmium in air measurements have been made post-1957 and some measurements were made in earlier years, but it has not been possible as yet to estimate exposure levels by department and calendar year. An idea of the practical difficulties involved may be found in a paper by King. ${ }^{12}$ Nevertheless, by considering the lowering of TLVs over recent decades and general descriptions of the improvements in working conditions, it was assumed

Table 7 Testing the null hypothesis of no effect from occupational exposure to cadmium on mortality from cancers of the respiratory system over levels of controlling variables by the method of RMLT†

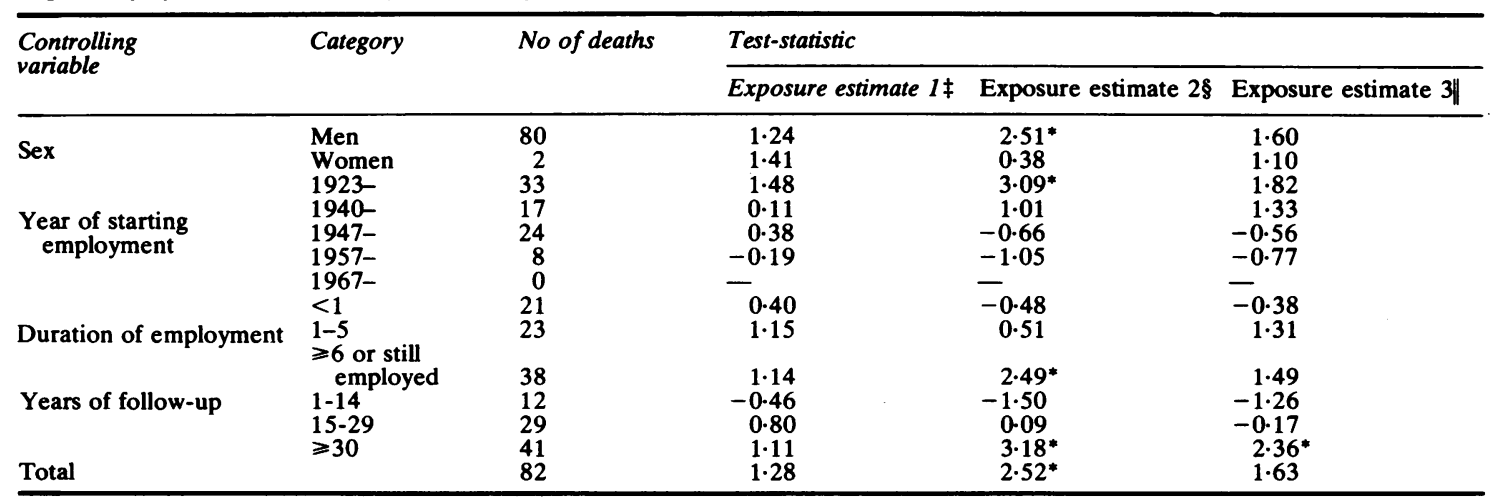

tControlling for the remaining three variables noted in table 6 .

$\ddagger$ Exposure = duration of employment in a high exposure job.

8xposure $=$ duration of employment in a high or moderate exposure job.

Exposure $=$ duration of employment in a high or moderate exposure job excluding welding.

Defined as duration between starting first period of employment and leaving last period of employment.

${ }^{*} \mathrm{p}<0.05$. 
Table 8 Testing the null hypothesis of no effect occupational exposure to cadmium on causes of death under investigation by the method of RMLT† with an estimated reduction $\ddagger$ in exposure levels over calendar year periods

\begin{tabular}{llcc}
\hline Cause of death & ICD 8th & No of deaths & $\begin{array}{l}\text { Exposure estimate 18 } \\
\text { Test-statistic }\end{array}$ \\
\hline Cancer of prostate & 185 & 8 & $3 \cdot 52^{*}$ \\
Cancer of respiratory system & $160-163$ & 82 & $1 \cdot 18$ \\
Diseases of circulatory system & $390-458$ & 255 & $0 \cdot 34$ \\
$\quad$ Associated with hypertension & 11 & 214 & $1 \cdot 11$ \\
$\quad$ Remainder & $460-579$ & 41 & $-1 \cdot 35$ \\
Diseases of respiratory system & $490-493$ & 84 & $-0 \cdot 62$ \\
$\quad$ Bronchitis, emphysema, asthma & 53 & $-1 \cdot 35$ \\
\hline
\end{tabular}

†Controlling for sex, year of starting employment, age at starting employment, and duration of employment.

$\ddagger$ Assumes exposure levels post-1967 to be $40 \%$ of those existing previously and exposure levels post-1972 to be $10 \%$ of those existing initially.

\$Exposure = duration of employment in a high exposure job weighted by exposure levels set out above. $\neq$

Diseases of the circulatory system related to hypertension were considered to be hypertensive disease (400-404), ischaemic heart disease $(410-414)$, cerebrovascular disease excluding subarachnoid haemorrhage $(431-438)$, arteriosclerosis $(440)$. * $<<0.05$.

that exposure levels post- 1967 were $40 \%$ of those existing previously and that exposure levels post1972 were $10 \%$ of those existing initially. This is clearly a rough and ready procedure; nevertheless, it may indicate whether the results shown in table 6 (exposure estimate 1) would be materially altered if more accurate estimates of the reduction in exposure levels over time were available.

Test-statistics-allowing for this assumed degree of reduction in exposure levels-are shown in table 8 , and are little changed from those shown in table 6. The statistic for cancer of the prostate is marginally increased and the original statistic for cancer of the prostate is, therefore, unlikely to be due to an artifact caused by ignoring the reduction in exposure levels over time.

Increased numbers of deaths for analysis were obtained by considering those with cancer of the prostate mentioned in part I or part II of the death certificate. Mention of cancer of the prostate appeared in part II of the death certificate for one of the cases of prostatic cancer reported by Kipling and Waterhouse. ${ }^{3}$ The extent to which new evidence is contributing to the statistically significant statistic for cancer of the prostate could thus be gauged by excluding the original four cases of cancer of the prostate from the calculations.

Table 9 shows the findings for cancer of the prostate (all deaths). The test-statistic for exposure estimate 1 is little changed. The effect of excluding the four previously reported cases of prostatic cancer is to reduce the statistically significant positive statistic (exposure estimate 1) to a small non-significant negative statistic. Thus no new evidence has been produced which suggests an association between occupational exposure to cadmium and cancer of the prostate.

Test-statistics, for causes of death detailed in table 6 , were also calculated for (1) exposure estimate 1
Table 9 Testing the null hypothesis of no effect from occupational exposure to cadmium on mortality from cancer of the prostate by the method of RMLT, $\dagger$ death included if cause mentioned in part I or part II of the death certificate

\begin{tabular}{|c|c|c|c|}
\hline Cause of death & $\begin{array}{l}\text { ICD } \\
8 t h\end{array}$ & No of deaths & $\begin{array}{l}\text { Exposure } \\
\text { estimate } 1 \ddagger \\
\text { Test-statistic }\end{array}$ \\
\hline $\begin{array}{l}\text { Cancer of prostate } \\
\text { Cancer of prostate } \S \\
\text { (with exclusions) }\end{array}$ & $\begin{array}{l}185 \\
185\end{array}$ & $\begin{array}{r}10 \\
6\end{array}$ & $\begin{array}{c}3.10^{*} \\
-0.32\end{array}$ \\
\hline
\end{tabular}

tControlling for sex, year of starting employment, age at starting employment, and duration of employment.

$\ddagger$ Exposure $=$ duration of employment in a high exposure job. $\S$ Excluding the four cases of cancer of the prostate reported by Kipling and Waterhouse. ${ }^{3}$

* $p<0.05$.

without the inclusion of duration of employment as a controlling variable, (2) exposure estimate 2 without the inclusion of duration of employment as a controlling variable, (3) duration of employment in a high exposure job weighted by time since exposure occurred, and (4) duration of employment in a high exposure job weighted by time since exposure occurred and allowing for the assumed degree of reduction in exposure levels with time indicated in table 8 . The resultant test-statistics were not materially changed for those shown in table 6 .

\section{Discussion}

The reasonableness of any approach using an internal standard depends on one main assumption: that we are comparing like with like, that after controlling for certain variables, exposed and non-exposed workers in a given year of follow up in a given subgroup are similar with respect to factors other than exposure.

In this study cohort all were workforce employees 
in one industry (one factory after 1947) and nearly all lived in the immediate locality. Some of the earlier personnel records are known to have been destroyed and the low SMR found for all causes among Ea men seems to be the result of a "survivor population effect," with data for the earlier entrants into the industry tending to be available for those who had remained in employment until after the 1947 amalgamation.

In recent years job applicants with a history of lung or kidney diseases have not been employed in high exposure jobs, and this selection process would, to some extent, work against the demonstration of any potential "hazard" for certain diseases.

The power of any mortality study must depend on the number of (cause-specific) deaths available for analysis, on the method of analysis adopted, and on the extent of discrimination in exposure within subcohorts.

The principal exposure variable used in this analysis (duration of high exposure employment) is relatively crude but is believed to be the most "realistic" estimate currently available. As stated above, however, the inclusion of moderate exposure employment in the "non-exposed" grouping would also, to some extent, work against the demonstration of any potential hazard. Furthermore, although this is a "long" follow up study with some 599 deaths available for analysis, only $12 \%$ of those who died had had more than five years' high exposure employment, whereas some $24 \%$ of those who died had had more than five years high or moderate exposure employment.

If occupational exposure to cadmium oxide is a risk factor for cancers of the respiratory system these factors may be the explanation for finding a statistically significant statistic for exposure estimate 2 but not finding a similar result for exposure estimate 1 . If no such risk exists, however, this finding may be a consequence of (1) possible risks associated with oxy-acetylene welding (as indicated by the statistics found for exposure estimate 3), (2) exposure to nickel hydroxide,,$^{1314}$ or (3) mere chance. Data on smoking habits were unfortunately not available, although there is no reason to believe that smoking habits would correlate with duration of exposed employment. If such a correlation were the explanation for the findings for cancers of the respiratory system, similar associations might be expected for other diseases of the respiratory system and for diseases of the circulatory system. Such associations were not found.

It must be emphasised that this analysis cannot distinguish between exposure to cadmium oxide dust and exposure to nickel hydroxide, because with the exception of one high exposure job (active mat- erial), all jobs entailing high cadmium exposures were also associated with high nickel exposures.

Nevertheless, given the above limitations, the analyses carried out on these data have suggested that for those workers occupationally exposed to cadmium oxide (hydroxide) dust there was (1) an increased risk of mortality from cancer of the prostate, which was entirely dependent on the original four cases reported by Kipling and Waterhouse ${ }^{3} ;(2)$ no association shown with mortality from cancer of the prostate for cases subsequent to the initial report $^{3}$; (3) no association shown with mortality from diseases of the circulatory system; (4) some indication of an increased risk of mortality from cancers of the respiratory system among those first employed before 1940, although exposure to oxyacetylene welding fumes and to nickel hydroxide dust were important confounding exposures; and (5) no association shown with mortality from other diseases of the respiratory system.

The debate on the possible carcinogenity of cadmium may be separated into two parts: (1) are cadmium compounds potentially carcinogenic-that is, would workers exposed to high levels over a long period suffer an increased risk of developing cancer? and (2) what increased risk would be experienced by workers exposed to current TLVs?

This analysis has not provided convincing new evidence that cadmium oxide is potentially carcinogenic. If this should be the case, however, then given that current exposure levels are possibly some two orders of magnitude lower than pre-1947 exposure levels (rather than the one order of magnitude assumed for some calculations) current risks are likely to be small. This is clearly an area for further research and careful monitoring.

\section{References}

' Sorahan T. A mortality study of nickel-cadmium battery workers. Proceedings of third international cadmium conference, Miami, 1982. London: Cadmium Association, 1982:138-41.

${ }^{2}$ Potts CL. Cadmium proteinuria - the health of battery workers exposed to cadmium oxide dust. Ann Occup Hyg 1965;8:5561.

${ }^{3}$ Kipling MD, Waterhouse JAH. Cadmium and prostatic carcinoma. Lancet 1967;i:730-1.

4 Lemen RA, Lee JS, Wagoner JK, Blejer HP. Cancer mortality among cadmium production workers. Ann NY Acad Sci 1976;271:273-9.

${ }^{5}$ Holden $\mathrm{H}$. Further mortality studies in workers exposed to cadmium fume. In: Occupational exposure to cadmium. London: Cadmium Association, 1980:23-4.

- Friberg L. Proteinuria and kidney injury among workmen exposed to cadmium and nickel dust. J Ind Hyg Toxicol 1948;30:32-6.

' Adams RG, Harrison JF, Scott P. The development of cadmium-induced proteinuria, impaired renal function, and osteomalacia in alkaline battery workers. $Q J \mathrm{Med}$ 1969;38:425-43. 
- Sorahan T, Adams RG, Waterhouse JAH. An analysis of mortality from nephritis and nephrosis among nickel-cadmium battery workers. JOM (in press).

' Liddell FDK, McDonald JC, Thomas DC. Methods of cohort analysis with appraisal by application to asbestos mining Journal of the Royal Statistical Society 1977;A140:469-91.

10 Cox DR. Regression models and life-tables. Journal of the Royal Statistical Society 1972;B34:187-219.

"Kneale GW, Mancuso TF, Stewart AM. A cohort study of the cancer risks from radiation to workers at Hanford. $\mathrm{Br} J$ Ind
Med 1981:39:156-66

${ }^{12} \mathrm{King}$ E. Techniques for the measurement of cadmium in air. In: Occupational exposure to cadmium. London: cadmium Association, 1980: 7-11.

${ }^{13}$ Sunderman FW. A review of the carcinogenesis of nickel, chromium, arsenic compounds in man and animals. Prev Med 1976;5:279-94.

14 International Agency for Research on Cancer. Evaluation of carcinogenic risks of chemicals to man. Vol II. Lyon: IARC, 1976

\section{Statistical appendix}

Define subgroups by cross classification of controlling variables. For each subgroup construct a life table as follows.

\begin{tabular}{|c|c|c|c|c|c|c|}
\hline $\begin{array}{l}\text { Year } \\
\text { of } \\
\text { follow up }\end{array}$ & $\begin{array}{l}\text { Survivors } \\
\text { entering } \\
\text { year of } \\
\text { follow un }\end{array}$ & $\begin{array}{l}\text { Mean } \\
\text { cumulative } \\
\text { exposure of } \\
\text { survivors }\end{array}$ & $\begin{array}{l}\text { Deaths } \\
\text { from } \\
\text { cause under } \\
\text { investigation }\end{array}$ & $\begin{array}{l}\text { Mean } \\
\text { cumulative } \\
\text { exposure } \\
\text { deaths }\end{array}$ & $\begin{array}{l}\text { Deviation } \\
\text { in } \\
\text { exposure }\end{array}$ & Variance \\
\hline $\begin{array}{l}1 \\
2\end{array}$ & $\begin{array}{l}\mathrm{N}_{1} \\
\mathrm{~N}_{2}\end{array}$ & $\begin{array}{l}\mathrm{X}_{1} \\
\mathrm{X}_{2}\end{array}$ & $\begin{array}{l}\mathbf{M}_{1} \\
\mathbf{M}_{2}\end{array}$ & $Y_{2}^{1}$ & $\begin{array}{l}D_{1} \\
D_{2}\end{array}$ & $\begin{array}{l}V_{1} \\
V_{2}\end{array}$ \\
\hline . & $\cdot$ & $\cdot$ & $\cdot$ & . & $\cdot$ & . \\
\hline . & $\cdot$ & $\cdot$ & $\cdot$ & . & $\dot{.}$ & $\dot{.}$ \\
\hline . & . & . & . & . & . & . \\
\hline such that & $\mathbf{N}_{\mathbf{i}}$ & $\mathbf{X}_{\mathrm{i}}$ & $\mathbf{M}_{\mathbf{i}}$ & $Y_{i}$ & $D_{i}$ & $\mathbf{V}_{\mathbf{i}}$ \\
\hline $\begin{array}{l}D_{i}=\left(Y_{i}\right. \\
\text { and }\end{array}$ &. $\mathbf{M}_{\mathbf{i}}$ & & & & & \\
\hline
\end{tabular}

$$
V_{i}=M_{i} \cdot\left[1-\frac{M_{i}}{N_{i}}\right] \cdot\left[\frac{\sum_{j=1}^{N_{i}} e^{2}-\left(\sum_{j=1}^{N_{i}} e_{j}\right)^{2} / N_{i}}{N_{i}-1}\right]
$$

where $e_{j}$ is the exposure of the $j$ th individual in the category $N_{i}\left(j=1,2 \ldots \ldots N_{i}\right)$. The variance is calculated using a finite population sampling formula. The deviations and variances may be summed over all years of follow up for each subcohort, over all subcohorts for each year of follow up, or over all years of follow up and all subcohorts.

$$
\begin{aligned}
& D=\Sigma D_{i} \\
& V=\Sigma V_{i} \\
& T=\frac{D}{\sqrt{V}}
\end{aligned}
$$

The test-statistic, $T$, is asymptotically normally distributed.

If no deaths occur in a given year of follow up in a given subgroup that strata is non-informative, and no contribution is made to the test-statistic. 